Stanistaw Chrobak*

Warszawa

\title{
Wychowanie do przebaczenia w pedagogii salezjańskiej
}

Problematyka wychowawcza dotyczy zawsze konkretnego człowieka. W odniesieniu do określonego człowieka mówi się o jego dzieciństwie, wieku młodzieńczym, latach dojrzałych itd. Uwaga zwrócona na realistyczne istnienie człowieka pozwoli także dookreślić „rzeczywistość wychowania”. Wychowawca staje więc wobec wychowanka jak wobec osoby, musi spotkać się z wychowankiem w jego niepowtarzalnym fakcie „bycia osobą”.

Myśląc o systemie prewencyjnym i szukając wzorca na dzisiaj, należałoby ponownie odkryć kryteria rozumu, religii i dobroci, które mogą być pomocne dla młodego człowieka w rozeznaniu, ocenie i zorganizowaniu własnych wyborów oraz w działaniu zgodnym z osobistym projektem życia. [...] Ksiądz Bosko uczył wychowawców życia z młodzieżą, bycia obok niej, pracy dla niej na wzór rodziny respektującej własny rytm rozwoju, zdolnej do głębokiego przenikania potrzeb młodych ludzi, rozumienia języka, jakim mówią, dostrzegania ich oczekiwań i pilnej potrzeby otwierania się na nowy świat ${ }^{1}$.

* Ks. dr hab. Stanisław Chrobak, prof. UKSW, jest profesorem w Katedrze Historii Wychowania i Dziejów Oświaty, na Wydziale Nauk Pedagogicznych Uniwersytetu Kardynała Stefana Wyszyńskiego w Warszawie. Adres: Wydział Nauk Pedagogicznych UKSW, ul. Wóycickiego 1/3, budyneknr 15,01-938 Warszawa; e-mail: s.chrobak@uksw.edu.pl.

1 Severino De Pieri, Ukierunkowanie w wychowaniu i towarzyszenie powołaniu (Warszawa: Wydawnictwo Salezjańskie, 2002), 14-15. 
Chciał powiedzieć, że edukacja nie jest wyłącznie kwestią narzucenia niechętnie lub nawet dobrowolnie wypełnianych przyjętych reguł, ale że nauczyciel (wychowawca) powinien dotrzeć do każdego młodego człowieka.

Chcecie osiągnąć wiele u waszej młodzieży - mówił ks. Bosko - nie okazujcie żadnemu z nich, że jesteście na niego zagniewani lub obrażeni. Znoście ich błędy, poprawiajcie je, ale też i zapominajcie. Okazujcie im waszą życzliwość. Niech zrozumieją, że wasze wszystkie zabiegi mają na celu jedynie ich szczęście doczesne i wieczne²

Jest to pełne, praktyczne uczestnictwo w świecie młodych. W tym też kontekście, poprzez refleksję nad postawą wychowawczą księdza Bosko i nad jego poczuciem odpowiedzialności za wychowanka, można konstruować wychowanie zorientowane na różne wartości trwałe - wartości, z którymi do wychowanka wychodzimy.

W procesie wychowania, zachodzącym pomiędzy wychowawcą i wychowankiem, wychowawca podejmuje świadome działania na rzecz poszerzenia i ubogacenia repertuaru zachowań oraz postaw wychowanka. Wychowawca sądzi, że nabycie przez wychowanka nowych zachowań, przyswojenie sobie określonych postaw, jak też wartości i norm społecznych, jest istotne dla wychowanka i chce doprowadzić do zbliżenia między wychowankiem a danym celem. Tak rozumiane wychowanie prowadziłoby do korzystnej zmiany w postawie wychowanka, a więc do pojawienia się i wzmocnienia nowych oraz pozytywnych zachowań. Jedną z wartości istotnych w życiu człowieka jest przebaczenie. Jest ono wartością zarówno w sensie obiektywnym, jak i subiektywnym. Przebaczenie zasługuje na to, aby je cenić, przede wszystkim ze względu na pozytywne skutki, jakie przynosi osobie przebaczającej. Do tychże pozytywnych skutków należą:

1) uwolnienie się od ciągłego powracania do przeszłości;

2) odzyskanie dużej części energii psychicznej, którą można poświęcić na sprawy związane z teraźniejszością i przyszłością;

3) polepszenie relacji z innymi ludźmi, otwarcie się na innych, na ich potrzeby, przeżycia i doświadczenia;

4) pozbycie się uczucia, że jest się ofiarą, osobą skrzywdzoną, czyli kimś gorszym;

${ }^{2}$ Pozwól gwizdać szpakom. Wybór myśli i wskazań św. Jana Bosko dla młodzieży i starszych, red. Stanisław Szmidt (Warszawa: Wydawnictwo Salezjańskie, 1998), 24. 
5) przekonanie o umiejętności konstruktywnego poradzenia sobie w sytuacji trudnej, jaką jest doświadczenie krzywdy;

6) wzięcie odpowiedzialności za kształt własnego życia;

7) odzyskanie poczucia sensu życia ${ }^{3}$.

Przebaczenie może być rozpatrywane w obszarze teologii (w Biblii), w duchowości czy psychologii ${ }^{4}$, jak również w religiach niechrześcijańskich ${ }^{5}$. Należy do tych pojęć, które podlegają kształtowaniu i rozwojowi i „można rozumieć jako miejsce przedefiniowania osobistej tożsamości. W podwójnym sensie: zaskoczenia i nowości, która uderza i przemienia człowieka, który otrzymuje przebaczenie, lecz również transformacji, zmiany perspektywy («metanoia»), które zachodzą w człowieku, który umie przebaczać»6. W przebaczeniu chodzi zatem o wewnętrzny i prawdziwy akt decyzji. Przebaczenie jest budowaniem nowego ładu wewnętrznego, konstruktywnym porządkowaniem sfery uczuć, wyobrażeń i sposobów reagowania, które zostały kiedyś doświadczeniem krzywdy zburzone. W psychologicznym wymiarze tego zjawiska przypomina pod pewnymi względami ,przesunięcie zwrotnicy na tor”: „To zależy ode mnie”. Przyszłość jest związana z przeszłością, lecz nie jest w niej uwiązana ani zamknięta ${ }^{7}$. W tym też kontekście można nakreślić następujące charakterystyczne właściwości przebaczenia:

1) doświadczenie przebaczenia włącza się w proces życia przeżytego dość specyficznie, a zwłaszcza gdy jest analizowane w przypadku osoby, która popełniła czyn, za który prosi o przebaczenie;

${ }^{3}$ Por. Marian Nowak, Podstawy pedagogiki otwartej. Ujęcie dynamiczne w inspiracji chrześcijańskiej (Lublin: Redakcja Wydawnictw Katolickiego Uniwersytetu Lubelskiego, 1999), 274-277; Aldona Król, „Wychowanie do przebaczenia”, w: Wychowanie chrześcijańskie między tradycją a wspótczesnością, red. Alina Rynio (Lublin: Wydawnictwo KUL, 2007), 432-435.

${ }^{4}$ Por. Zbigniew Narecki, ,Wartość przebaczenia i pojednania w pryzmacie współczesności”, Pedagogia Ojcostwa 10, 1 (2015): 40-43.

5 Por. Eugeniusz Sakowicz, „Przebaczenie w religiach niechrześcijańskich”, Ateneum Kapłańskie 156, 2 (2011): 270-275.

${ }^{6}$ Mario Aletti, „Przedmowa. Przebaczenie i przedefiniowanie osobistej tożsamości”, w: Annalisa Giulianini, O przebaczaniu, czyli jak uleczyć duszę. Psychologiczne i duchowe sprzeczności (Kraków: Wydawnictwo OO. Franciszkanów „Bratni Zew”, 2008), 8.

${ }^{7}$ Por. Mirosław Nowosielski, „Przebaczenie - trudny problem widziany z perspektywy psychologicznej”, Ateneum Kaptańskie 156, 2 (2011): 228-231. „Dla tych, którzy nie potrafią przebaczyć, nie ma nadziei na przyszłość albo też te nadzieje są poważnie ograniczone. Wszystko, co najlepsze, już minęło, już się skończyło. Niczego już nie oczekują. Przebaczenie, uzdrawiając pamięć, uwalnia od ciężaru przeszłości i z nadzieją pozwala patrzeć w przyszłość" (Tadeusz Gadacz, O ulotności życia (Warszawa: Wydawnictwo Iskry, 2008), 38). 
2) także ten, kto udziela przebaczenia, potrzebuje czasu i wysiłku, żeby przebaczyć;

3) przebaczenie, nawet jeśli utożsamia wydarzenie intymne i osobiste, nie odnosi się do siebie, ponieważ zawsze implikuje relację intersubiektywną;

4) przebaczenie otwiera nowe scenariusze, nowe horyzonty, zmienia oblicze naszych ludzkich relacji, przemienia to, co zdawało się być niemożliwym do odzyskania, nie do zniesienia, otwiera nowe początki, nowe możliwości życia ${ }^{8}$.

Przebaczenie nie jest tylko prostą reakcją (np. na słowo „przepraszam") wobec tych, którzy zawiedli, zranili, skrzywdzili. Jest to złożony proces psychologiczny, w którym zaangażowane są struktury poznawcze, emocjonalne i działaniowe. W procesie wychowania uwaga wychowawców, rodziców winna być koncentrowana na kształtowaniu i stymulowaniu czynników sprzyjających procesowi przebaczenia oraz eliminowaniu, o ile to jest możliwe, czynników utrudniających przebaczenie. Skoro zdolność przebaczenia jest wyrazem rozwoju osobowości, to podobnie jak cała osobowość podlega ona kształtowaniu i rozwojowi, a więc musi znaleźć swoje miejsce w procesach samowychowania i samorealizacji. Przede wszystkim jednak przebaczenie jest możliwe, gdy jego fundamentem są wykształcone relacje ze światem wartości, transcendencją, Bogiem ${ }^{9}$. Przebaczenie jest jednym z centralnych elementów kultury chrześcijańskiej. Wychowanie religijne, pomaganie dziecku we wchodzeniu w prawdziwie osobową relację z Bogiem, kształtowanie prawdziwego obrazu Boga, jako Osoby kochającej i troszczącej się o jego dobro na wszystkich płaszczyznach życia, jest fundamentem wychowania do przebaczenia ${ }^{10}$. Można zatem stwierdzić, iż ,jest to akt dynamiczny, przekształcający, który nie implikuje jedynie zmiany w wewnętrznym nastawieniu osoby, która przebacza, lecz wywołuje efekty także w osobie, która dostępuje przebaczenia, powoduje zmianę w jej sytuacji" 11 . Przebaczenie to temat trudny, wielowątkowy, skomplikowany, dotykający

${ }^{8}$ Por. Emanuele Balduzzi, La pedagogia alla prova della virtù. Emozioni, empatia e perdono nella pratica educativa (Milano: Vita e Pensiero, 2015), 154-157.

${ }^{9}$ Por. Krystyna Ostrowska, Wokół rozwoju osobowości i systemu wartości (Warszawa: Centrum Metodyczne Pomocy Psychologiczno-Pedagogicznej Ministerstwa Edukacji Narodowej, 1998), 50-54.

${ }^{10}$ Por. Król, „Wychowanie, 441-442.

${ }^{11}$ Annalisa Giulianini, O przebaczaniu, czyli jak uleczyć duszę. Psychologiczne i duchowe sprzeczności (Kraków: Wydawnictwo OO. Franciszkanów „Bratni Zew”, 2008), 33. 
najgłębszych pokładów ludzkiego ducha. W proponowanym krótkim artykule przedmiotem naszego zainteresowania są przede wszystkim główne zasady (podstawy) systemu prewencyjnego Jana Bosko oraz przebieg procesu wychowania do przebaczenia w pedagogii salezjańskiej.

\section{System prewencyjny Jana Bosko}

System prewencyjny, który przez samego św. Jana Bosko (1815-1888) nie został określony teorią, koncepcją, ale właśnie „systemem”, powstał jako odpowiedź na potrzeby wychowawcze związane z konkretnym środowiskiem XIX wieku we Włoszech. Jest to synteza jego myśli pedagogicznej, wyrosłej z długiego i bogatego doświadczenia wychowawczego (od 1841 roku, kiedy to zainicjował ,wędrowne” oratorium świąteczne). Oryginalność księdza Bosko polega na tym, że jako człowiek i wychowawca zrealizował na wyjątkowo wysokim poziomie postulat rozumienia młodzieży i dzielenia jej życia, a skłoniło go do tego głębokie zainteresowanie światem młodzieży i niezwykła pasja wychowawcza. Żył w sercu Risorgimento (ruch ideowy i polityczny, związany z walką o wyzwolenie narodowe i zjednoczenie Włoch; także okres 1815-1870 w historii Włoch), okresu głębokich przeobrażeń i olbrzymich problemów w dziedzinie politycznej, społecznoekonomicznej, kulturalno-wychowawczej i religijnej. W dobie zaognionego radykalizmu Jan Bosko proponował swoje alternatywne podejście: nie ma sprzeczności między byciem obywatelem i byciem chrześcijaninem, bo zaangażowany chrześcijanin jest - lub powinien być - dobrym i uczciwym obywatelem $^{12}$. System prewencyjny zatem nie może być oddzielony od osoby księdza Bosko i od charakteru instytucji, w których on i jego współpracownicy działali. $Z$ tak postawionej kwestii wynika, że fundamentalne linie działania prewencyjnego mogą być zrozumiałe tylko wówczas, gdy będą postrzegane $\mathrm{w}$ ścisłym związku $\mathrm{z}$ jego biografią, $\mathrm{z}$ jego temperamentem i podstawowymi wymiarami jego osobowości. Źródłem systemu prewencyjnego pozostaje dla księdza Bosko jego charyzmat, u podstaw którego leżała postawa ludzko-chrześcijańska, postawa poszukiwania dobra osoby poprzez relację przyjazną, serdeczną, autentyczną ${ }^{13}$.

12 Por. Luciano Cian, Wychowanie w duchu Księdza Bosko (Warszawa: Wydawnictwo Salezjańskie, 1990), 179-185.

${ }_{13}$ Por. Pietro Braido, Prevenire non reprimere. Il sistema educativo di don Bosco (Roma LAS, 1999), 158. 
Idea prewencyjna była i jest obecna w całej historii wychowania chrześcijańskiego i oznacza takie działania, jak: zapobieganie, zabezpieczenie, ochrona, przygotowanie, przewidywanie. W instytucjach o charakterze charytatywnym ujawnia się jako działanie zmierzające do zaspokojenia materialnych potrzeb człowieka. W tym też kontekście ks. Jan Bosko w swoich ośrodkach wychowawczych przejął i rozwinął ideę prewencyjną, stając się nowym interpretatorem tejże idei. Dążył on do poszukiwania takich założeń, metod, środków i form wychowania, by sprzyjały pełnemu, integralnemu rozwojowi młodego człowieka ${ }^{14}$.

Gdy chodzi o księdza Bosko, założyciela wielkiej rodziny duchowej - stwierdza Jan Paweł II - można powiedzieć, że charakterystyczny rys jego «genialności» wiąże się z praktyką wychowawczą, którą on sam nazwał «systemem prewencyjnym» [...] Używany przez Świętego termin «prewencyjny» należy pojmować nie tyle w sensie dosłownym, ale raczej jako określenie bogactwa cech charakterystycznych, właściwych jego sztuce wychowawczej. Podkreśla on przede wszystkim wolę zapobiegania powstawaniu negatywnych doświadczeń, które mogłyby osłabić zapał młodego człowieka lub narazić go na długie i mozolne odrabianie strat. Określenie to zawiera także przeżyte ze szczególnym natężeniem głębokie intuicje, ściśle określone wybory i kryteria metodologiczne, takie jak sztuka wychowania pozytywnego, ukazująca dobro właściwych i angażujących doświadczeń, urzekających szlachetnością i pięknem; sztuka pomagania młodym w «wewnętrznym wzrastaniu» przez rozbudzanie ich wewnętrznej wolności oraz przezwyciężanie zewnętrznych uwarunkowań i formalizmów; sztuka pozyskiwania młodzieńczych serc, by z radością i zadowoleniem zapalać je do dobra, prostując wypaczenia i przysposabiając do przyszłych zadań poprzez rzetelną pracę nad charakterem ${ }^{15}$.

Jan Bosko, wychodząc od dogłębnych rozważań ówczesnych sytuacji, przedstawił podstawowe założenia antropologiczne, pedagogiczne, teologiczne i duszpasterskie, które wykorzystał w wychowaniu młodzieży swoich czasów. „System ten - stwierdza - opiera się całkowicie na rozumie, religii

${ }^{14}$ Por. Kazimierz Misiaszek, „Pedagogia salezjanów”, w: Pedagogie katolickich zgromadzeń zakonnych. Historia i wspótczesność, t. 1, red. Janina Kostkiewicz (Kraków: Impuls, 2012), 234-239.

15 Jan Paweł II, „List apostolski Iuvenum patris w setną rocznicę śmierci św. Jana Bosko", w: Ksiądz Bosko w wypowiedziach papieży, cz. 2, red. Stanisław Chrobak (Warszawa: Wydawnictwo Salezjańskie, 2015), 81. 
i dobroci"16. Te trzy podstawowe zasady nie tylko wzajemnie się przenikają, ale także warunkują. W tym też kontekście:

- „rozum” - zgodnie z autentyczną wizją chrześcijańskiego humanizmu podkreśla godność osoby. Godność osoby jest wewnętrznym, wrodzonym i naturalnym znamieniem człowieka, niezależnym od kontekstu społecznego i historycznego. Uszanowanie godności osoby sprawia, że wychowanie staje się służbą dla rozwoju człowieka. W tym też kontekście „rozum” oznacza także mądrość, rozsądek, prostotę, naturalność, przyjacielskość, gotowość do dialogu i uznanie konieczności, by wychowanek w miarę swych możliwości dokonywał wyborów i podejmował decyzje, oraz zaproszenie młodych do uczestnictwa w wartościach zrozumiałych i podzielanych. „Rozum” zapoczątkowuje cały proces wychowania - najpierw wychowanek musi wiedzieć, co ma robić, a potem należy mu pomóc o tym pamiętać, by rozumne myślenie stało się cechą wychowanka, przekształcając się w świadomość faktycznej osobistej odpowiedzialności.

Rozum - podkreśla Juan E. Vecchi - jest w całości wymiarem tego, co możemy nazwać naturą ludzką [...]. Zawiera również całą kulturę, jej dzieła i wyniki: wszystko, co zostało świadomie wypracowane. Co się tyczy osoby, rozum oznacza mądrość, równowagę, umiarkowanie, zdolność opanowania własnych skrajnych zachowań, zdolność postępowania z pobudek, które pojmuje umysł. [...] wszystko to, co człowiek wypracowuje własnym wysiłkiem, ale człowiek, który wychodząc od racjonalności otwiera się na transcendencję ${ }^{17}$;

- „religia” - wskazuje, że pedagogia księdza Bosko jest w swej istocie transcendentna, ponieważ ostatecznym celem wychowawczym jest ukształtowanie człowieka wierzącego. Ksiądz Bosko w religii widzi przede wszystkim drogę do serca, umysłu i duszy młodego człowieka oraz pomoc w osią-

16 Jan Bosko, „System prewencyjny w wychowaniu młodzieży”, w: Współczesny wychowawca w stylu księdza Bosko, red. Józef Wilk (Lublin: Poligrafia Inspektoratu Towarzystwa Salezjańskiego, 1998), 213-214. Na temat systemu prewencyjnego zobacz m. in.: Il sistema preventivo e l'educazione dei Giovani, red. Carlo Nanni (Roma: LAS, 1989); Luciano Cian, Wychowanie w duchu Księdza Bosko (Warszawa: Wydawnictwo Salezjańskie, 1990); Reinhold Weinschenk, Podstawy pedagogiki Księdza Bosko (Warszawa: Wydawnictwo Salezjańskie, 1996); Luciano Cian, System zapobiegawczy św. Jana Bosko i jego charakterystyka (Warszawa: Wydawnictwo Salezjańskie, 2001); Cesare Bissoli, Jan Pawet II o systemie wychowawczym księdza Bosko (Warszawa: Wydawnictwo Salezjańskie, 2001).

17 Juan E. Vecchi, Strażnicy marzeń z palcem na myszce. Wychowawcy w dobie informatyki (Warszawa: Wydawnictwo Salezjańskie, 2001), 165. 
ganiu pełni osobowego rozwoju człowieka. To religia motywuje człowieka do dobra, ukazuje sens jego życia i poświęcenia, zachęca do działania na rzecz dobra wspólnego. Idea religijności wiąże się ściśle z wyżej omawianą zasadą rozumności, przestrzegając przed religijnością magiczną, zbyt powierzchowną, nadmiernie uczuciową oraz redukowaniem religii do nauczania reguł, zasad i definicji. Tak rozumiana zasada oznacza wiarę żywą, zakorzenioną w rzeczywistości, a nie jakąś religię abstrakcyjną. Formacja religijna, jaką proponuje ks. Jan Bosko, prowadzi do pełnego rozwoju osobowego człowieka, wiąże formację osobistą z formacją do życia rodzinnego i społecznego.

W jego rozumieniu człowiek uformowany i dojrzały to wierzący obywatel, taki, który swoje życie koncentruje wokół obwieszczonego przez Jezusa Chrystusa ideału człowieka nowego i który odważnie wyznaje swoje przekonania religijne. [...] Ten aspekt religijnej transcendencji, podstawa metody wychowawczej księdza Bosko, nie tylko daje się stosować w każdej kulturze, lecz może okazać się owocny także w religiach niechrześcijańskich ${ }^{18}$;

- „miłość wychowawcza” - miłość rozpatrywana w klimacie rozumu i religii oznacza przede wszystkim poszanowanie młodego człowieka. Jest to sposób bycia wyrażający sympatię, zrozumienie, współczucie, zaufanie, współuczestnictwo w życiu drugiego człowieka. Okazywana miłość to miłość ludzka, mądra, odrzucająca chorobliwą przesadę sprowadzającą człowieka do roli instrumentu. Miłość wychowawcza ma prowadzić wychowanka ku pełnej dojrzałości, odpowiedzialności i samodzielności. Realizacja tak rozumianej „miłości wychowawczej” jest dla księdza Bosko w pierwszym rzędzie miłością ewangeliczną i opiera się całkowicie na słowach św. Pawła: „miłość cierpliwa jest..., wszystko znosi..., we wszystkim pokłada nadzieję..., wszystko przetrzyma..." (por. 1 Kor 13, 4-7). Taka perspektywa sprawia - i jest to myśl ks. Bosko - że wychowawca jest swoistym nosicielem miłości Boga do młodzieży. W jego miłości do Boga mieści się upraktycz-

18 Jan Paweł II, „List apostolski Iuvenum patris, 83. „Działając na rzecz wychowania moralnego, obywatelskiego, kulturowego ludzi młodych, Ksiądz Bosko angażował się dla dobra poszczególnych osób i społeczeństwa obywatelskiego, według planu człowieka, który łączy razem radość - naukę - modlitwę, jak też pracę - religię - cnoty. Integralną częścią tej drogi jest dojrzewanie powołaniowe, tak aby każdy podjął w Kościele konkretną formę życia, do której wzywa go Bóg” („Jak ksiądz Bosko, z młodzieżą i dla młodzieży. List Ojca Świętego Franciszka w dwusetlecie urodzin św. Jana Bosko", w: Ksiądz Bosko w wypowiedziach papieży, cz. 2, red. Stanisław Chrobak (Warszawa: Wydawnictwo Salezjańskie, 2015), 284). 
niona i skonkretyzowana miłość do bliźniego, którym jest każdy młody człowiek, a zwłaszcza potrzebujący pomocy wychowawczo-rozwojowej. Miłość jest podstawową siłą wychowania i urzeczywistnia się we współdziałaniu. „Na określenie poprawnej relacji pomiędzy wychowawcami i wychowankami ksiądz Bosko lubił używać terminu familiaritá [zażyłość, przyjaźń]. Długoletnie doświadczenie przekonało go, że bez tej zażyłości nie można okazać miłości, a bez tego trudno o wzbudzenie zaufania, które jest niezbędnym warunkiem skuteczności pracy wychowawczej”"19.

Wychowanie powinno prowadzić do zrealizowania określonych celów. W osiąganiu zamierzonych celów wychowania może pomóc środek wychowawczy. Ważne środki w wychowaniu to między innymi: pochwała, nagroda, zachęta, wyróżnienie, zainteresowanie się wychowankiem i jego postawą, dobry przykład, przyjaźń, zabawa, wspólna praca, dialog, rozmowa, a także wyjaśnienie, przypomnienie, pouczenie, upomnienie, nagana, krytyka, kara. W takich działaniach chodzi o wzbudzenie w wychowanku wrażliwości moralnej na to, co nie jest słuszne, i zapobieganie konieczności wymierzania kary. W systemie prewencyjnym Jana Bosko zasadnicze znaczenie mają przede wszystkim asystencja wychowawcza i oratorium, dobry przykład oraz autorytet wychowawczy. Dawane przez księdza Bosko codzienne świadectwo, pełna dynamizmu obecność i rodzinna atmosfera, jaką stworzył w oratorium, budziły w młodzieży poczucie współpracy i współodpowiedzialności. Oratorium było i jest miejscem, w którym realizowane są wszystkie zasady wychowania prewencyjnego - integralnego rozwoju wychowanka. Istotnymi czynnikami wychowania oratoryjnego były i są: styl interakcji wychowawczej (chodzi o konieczność wytworzenia w oratorium klimatu rodzinnego, odznaczającego się stylem ojcowskim i braterskim); bezpośrednie relacje $\mathrm{z}$ wychowankiem (wychowanek ma wzrastać w przekonaniu o swojej indywidualności, rozumności, wolności, godności, jako osoba ludzka, mając zarazem świadomość potrzeby osobistego rozwoju, w którym to procesie jednym z podstawowych czynników jest personalna pomoc wychowawcy) i tak zwana asystencja (ciągła obecność wychowawcy wśród podopiecznych, aby towarzyszyć wychowankowi i wspierać go w dążeniu do dojrzałości) ${ }^{20}$.

19 Jan Paweł II, „List apostolski Iuvenum patris, 84.

20 Por. Marian Nowak, Teorie $i$ koncepcje wychowania (Warszawa: Wydawnictwa Akademickie i Profesjonalne, 2008), 461-464; Stanisław Chrobak, „Podstawowe wartości wspólnoty jako środowiska wychowawczego w systemie prewencyjnym św. Jana Bosko”, w: Kształtowanie się środowisk wychowawczych dzieci i młodzieży na przestrzeni dziejów, red. 


\section{Przebaczenie - intuicje wychowawcze Jana Bosko}

W wychowawczym systemie prewencyjnym św. Jana Bosko szczególne znaczenie przypisuje się wartościom podstawowym, nazywanym także wartościami ogólnoludzkimi, powszechnymi, uniwersalnymi lub ponadczasowymi ${ }^{21}$. Z uznawanych powszechnie wartości uniwersalnych i ponadczasowych wysoko cenił Jan Bosko przede wszystkim miłość i podkreślał iż: „prawdziwa miłość nakazuje błędy innych znosić $\mathrm{z}$ cierpliwością i chętnie przebaczać" 22 . Był przekonany, że nawet najbardziej przemyślany program oddziaływań wychowawczych, łącznie ze starannie opracowanym regulaminem, nie jest w stanie zastąpić osobistych i międzyludzkich relacji, znajdujących oparcie w szczerej i bezinteresownej miłości. Wychowanie do miłości sprzyja także przyswajaniu przez dzieci i młodzież innych podstawowych wartości.

Kto chce być kochanym - pisał Jan Bosko 10 maja 1884 roku - musi dać poznać, że sam kocha. [...] Nauczyciel widziany jedynie na katedrze jest tylko nauczycielem i niczym więcej; lecz jeśli przestaje z chłopcami na rekreacji, staje się niejako bratem. Jeśli się widzi kogoś przemawiającego $\mathrm{z}$ ambony, mówi się, że spełnia jedynie swój obowiązek; lecz jeśli powie jakieś słowo na rekreacji, będzie to słowo kogoś, kto miłuje. Przyczyną iluż to nawróceń były słowa szepnięte niespodziewanie w czasie rozrywki! Kto wie, że jest kochany, kocha, a kto jest kochany, uzyska wszystko, zwłaszcza od młodzieży. Zaufanie wytwarza jakby prąd elektryczny, który przechodzi między chłopcami a przełożonymi. Otwierają się serca, ujawniają swoje potrzeby i odkrywają swoje wady. Miłość pozwala przełożonym znosić trudy, natręctwa, niewdzięczność, przeszkadzanie, uchybienia, niedbalstwa chłopców ${ }^{23}$.

Barbara Moraczewska, Piotr Krzywicki (Włocławek: Państwowa Wyższa Szkoła Zawodowa we Włocławku, 2014), 143-146.

${ }^{21}$ Por. Mieczysław Łobocki, „Współczesne tendencje w wychowaniu a system wychowawczy św. Jana Bosko", w: Ksiądz Bosko i jego system wychowawczy, red. Jan Niewęgłowski (Warszawa: Wydawnictwo Salezjańskie, 2000), 264-267.

22 Pozwól, 44.

${ }^{23}$ Jan Bosko, „List z Rzymu”, w: Wspótczesny wychowawca w stylu księdza Bosko, red. Józef Wilk (Lublin: Poligrafia Inspektoratu Towarzystwa Salezjańskiego, 1998), 226. 
Myśl wychowawcza księdza Bosko jest umieszczona w kontekście wielkich wyzwań i potrzeb, odnosi się do samej natury działań prewencyjnych. Zatem, jak stwierdza Tadeusz Gadacz:

miłość zawsze odpłaca dobrem, jest niezasłużonym darem. [...] Przebaczenie jest dobrowolnym darem. Stosując użyteczne kryterium podziału wartości, wprowadzone przez Nicolaia Hartmanna, na wartości «niskie-silne» oraz «kruche-wysokie», przebaczenie należałoby zaliczyć do wartości kruchych i wysokich. Wartości wysokie, jak wiadomo, charakteryzują się tym, że nie mogą być chronione prawem i nakazane, na przykład tak jak chronione prawem mogą być życie lub własność, czyli wartości niskie-silne. Wartości wysokich możemy sobie co najwyżej życzyć i pragnąć. Mogą wypływać jedynie z wolności i wrażliwości. Dlatego także warunkiem i źródłem przebaczenia jest wolność, gdyż przebaczenie jest darem i darem jest też przyjęcie przebaczenia ${ }^{24}$.

„System prewencyjny jest miłosierdziem w działaniu”25. Przez miłość wychowawca tworzy klimat prawdziwej „,pedagogicznej obecności”, obecności twórczej i wyzwalającej, odsłania cały wieloproblemowy i wieloaspektowy kontekst uwarunkowań dla sytuacji i procesów wychowania, w tym także wychowania do przebaczenia.

Przebaczenie - jak podkreśla Josef Pieper - jest nawet jednym z podstawowych aktów miłości. Cóż to jednak dokładniej znaczy? W każdym razie nie znaczy, że «uznajemy za dobre» coś złego, że traktujemy zło niepoważnie, jakby chodziło tylko o przeoczenie. Przebaczyć można tylko coś, co wyraźnie uważa się za zło, czego negatywnych cech się właśnie nie ignoruje. Zresztą jedynie w taki sposób traktuje się poważnie osobistą godność drugiego człowieka. [...] w przebaczeniu kryje się założenie, że druga osoba sama potępia (,żałuje”) to, co uczyniła, i że ponadto akceptuje przebaczenie ${ }^{26}$.

${ }^{24}$ Gadacz, O ulotności, 33-34. „Pedagogika przebaczenia nie może funkcjonować jedynie na poziomie racjonalizacji zachowań, ale musi umieć sięgać w sferę emocjonalnej troski o jakość własnego człowieczeństwa ze strony ofiary w jej relacji z krzywdzicielem. [...] Zdolność umożliwiająca prawdziwe przebaczenie wymaga wzniesienia się do nowej szlachetności istnienia, gdyż wykracza ona poza pragmatyczną instrumentalność, będąc nową rozumnością duchową" (Julita Orzelska, W stronę pedagogiki istotnej egzystencjalnie (Kraków: Impuls, 2014), 157).

${ }^{25}$ Cyt. za: Cian, Wychowanie, 281.

26 Josef Pieper, O miłości (Warszawa: Instytut Wydawniczy Pax, 2004), 53. 
Zatem w systemie wychowawczym ks. Bosko w grę wchodzi całościowo pojęta postawa rozumnej miłości w wychowaniu. W rozumnej miłości wychowawczej ujawnia się jej uniwersalizm. W tak nakreślonej perspektywie $\mathrm{w}$ wychowaniu do przebaczenia w kontekście systemu prewencyjnego Jana Bosko ważny jest:

1) postulat podmiotowego traktowania dzieci i młodzieży. „W każdym chłopcu - stwierdzał Jan Bosko - nawet tym najgorszym, jest jakieś miejsce wrażliwe na dobro. Pierwszym i zasadniczym obowiązkiem wychowawcy jest właśnie odkrycie tego miejsca, tej wrażliwej struny jego serca, aby ją następnie wykorzystać w pracy wychowawczej"27. Samo podmiotowe traktowanie wychowanków nie oddziaływuje na nich automatycznie. Przebaczenie jest aktem pozytywnym, jest szansą nowego dobra. Chodzi tu o odkrycie w każdym wychowanku osoby rozumnej, wolnej i odpowiedzialnej, wrażliwej na dobro, prawdę i piękno, zdolnej do autorefleksji, samorealizacji, twórczości, transcendencji. Podmiotowe traktowanie wychowanka oznacza także szacunek i oddanie dla wychowanka, profesjonalne zorientowanie się wychowawcy, co faktycznie jest dziecku potrzebne w jego rozwoju, i to nie tylko finalnie, ostatecznie - ale i bieżąco, już teraz, w jego aktualnej sytuacji, potrzebach, w jego problemach wieku i dnia. „Nie ma takiego człowieka, który by robił wszystko źle, i że w każdym z nas znajduje się coś dobrego. Należy tylko zdać sobie z tego sprawę, z drzemiącego w nim dobra i pomóc mu obudzić je"28.

2) Jan Bosko, ilekroć mówi o wychowaniu, ma zawsze na myśli kontakt międzyosobowy, który znaczy więcej niż przypadkowe spotkanie. Tak rozumiane wychowanie apeluje do wewnętrznego dynamizmu wychowanka, aby zmobilizować i wzmocnić jego pozytywne wartości i aby odkryć oraz osłabić jego negatywy. Oznacza także umiejętność akceptowania wychowanków polegającą na uznaniu ich takimi, jakimi są naprawdę. Jest to pragnienie dobra dla wszystkich, także tych, którzy popełniają błędy, a zatem: „gdy jakiś chłopiec okazuje skruchę za popełnione wykroczenia, to wybaczcie mu i to wybaczcie z całego serca"29. Podkreślał, by obecność pedagogiczną rozpoczynać od przekonania pozytywnego i postawy dobroci, która pozwala przypuszczać, że młodzieży mogą się zdarzyć zachowania niewłaściwe i dlatego

27 Pozwól, 41-42.

${ }^{28}$ Giuseppe Pellegrino, Jak wychowywać? (Warszawa: Wydawnictwo Salezjańskie, 1994), 11

${ }^{29}$ Pozwól, 41. 
wychowawcy powinni z nimi być w taki sposób, by zapobiec popełnianiu wykroczeń.

\begin{abstract}
Pokażcie - stwierdza Jan Bosko - że nie wymagacie innej uległości niż ta, jaką nakazuje rozum i konieczność. Starajcie się sprawić, by winowajca sam siebie potępił i by wam nie pozostawało nic innego jak tylko złagodzić przyjętą przez niego karę. Zostaje jeszcze jedno zalecenie dotyczące tej poważnej kwestii. Kiedy pozyskacie sobie taką nieugiętą duszę, pozostawcie jej, proszę, nie tylko nadzieję na wasze przebaczenie, ale i na to, że dobrym sprawowaniem można zmazać plamę winy ${ }^{30}$.
\end{abstract}

Miłość jest wymagająca, ale zawsze rozumna. Młodzież musi wiedzieć, dlaczego podejmuje się takie, a nie inne decyzje. Czynny charakter miłości ujawnia się w trosce o innego, poszanowaniu, poznaniu i odpowiedzialności. To także nastawienie mocne i zasadnicze, które pozwala wychowawcy, gdy tego potrzeba, wyrażać się zewnętrznie w sposób zdecydowany, mocny, a nawet surowy. W tym też kontekście Jan Bosko nie bez powodu zauważa: „Nigdy nie wypominaj przebaczonej krzywdy, bo przebaczyć to znaczy zapomnieć na zawsze" ${ }^{31}$. Miłość, która jest czynnym zainteresowaniem życiem i rozwojem tego, kogo kochamy, wpływa na rozwijanie obrazu samego siebie i relacji do innych ludzi;

3) dla księdza Bosko oznaką miłości wychowawczej była tak zwana asystencja, czyli ciągłe przebywanie wychowawcy pomiędzy wychowankami. W jego regule ,asystencji” chodzi o obecność stałą, przyjacielską, solidarną, promocyjną, animującą i wspierającą wychowanka w jego stawaniu się „uczciwym obywatelem i dobrym chrześcijaninem”. W idei stałej i czuwającej asystencji akcent położony jest na pomoc, kierowanie rozwojem, zapobieganie wykroczeniom, a nie na kontrolowanie dla upominania i karania. Miłość wychowawcza to postawa wyrażana w sposób czytelny i konkretny. „Innym - podkreślał Jan Bosko - przebaczaj wszystko, sobie

${ }^{30}$ Jan Bosko, „List o karach”, w: Cian, Wychowanie, 265. Młodemu nauczycielowi ksiądz Bosko daje taką oto radę: „Doceniaj zawsze wszystkich i nikogo nie zniechęcaj” (cyt. za: Cian, Wychowanie, 188).

${ }^{31}$ Pozwól, 55. „Ksiądz Bosko był wychowawcą, który nie tylko przygarnia, lecz również proponuje, nie tylko wybacza, lecz również kieruje w stronę wysiłku. Nie jest jedynie «dobrotliwy», lecz posiada bardzo realistyczną i bogatą wizję życia" (Juan E. Vecchi, Duchowość salezjańska (Warszawa: Wydawnictwo Salezjańskie, 1999), 164). 
nic" ${ }^{32}$. Wychowuje się przede wszystkim i bardziej przez to, kim się jest, niż przez to, co się robi i mówi. Obecność pedagogiczna ma być współobecnością personalną wychowawcy z wychowankiem, który życzliwie stymuluje i kieruje wychowanka ku dojrzałości osobowej.

Proces wychowawczy przebiega zawsze tą samą drogą: «mistrz», głoszone przez niego wartości, obserwacja i weryfikacja. [...] Nauczyciel stawiający znak równości między profesjonalizmem i specjalistycznym przygotowaniem technicznym, ale niemający zamiłowania do szkoły i kultury, niebędący dla swych uczniów przewodnikiem, niekochający ich, nietraktujący swojej pracy jako nauczania nie tylko przedmiotu, ale życia, jest technikiem wychowania i niczym więcej ${ }^{33}$.

Przebaczenie jest w swej istocie zawsze indywidualne i międzyosobowe. Wychowawca nauczając, radząc, zachęcając, mówi coś o sobie, o tym, co wychowanek dla niego znaczy, o głębokim znaczeniu i motywacjach, które podtrzymują jego pracę. „Pełniąc zajęcie asystenta - stwierdza Jan Bosko pozwólcie wychowankom swobodnie wypowiadać swoje myśli; ale starajcie się poprawiać wyrażenia i przeszkadzać czynom niezgodnym z chrześcijańskim wychowaniem" 34 . Asystencja nie oznacza więc nadzoru, ale pełni funkcje zapobiegawcze przez eliminowanie tych elementów, które mogą zamącić normalny rozwój i wzrost sił wewnętrznych oraz jest zależna od wieku i dojrzałości wychowanka;

4) wyrazem miłości wychowawczej jest duch rodzinny. „Duch rodzinny rodzi miłość, a milość budzi zaufanie, które otwiera serca i chłopcy bez obawy zwierzają się ze wszystkiego przed nauczycielami, asystentami i przełożonymi" 35 . W prowadzonych przez księdza Bosko oratoriach, szkołach, internatach, hospicjach, warsztatach nie brakowało rodzinnego ciepła, miłości, zaufania, bliskości. W tworzeniu takiego projektu wychowania odwoływał się do osobistych doświadczeń życia rodzinnego, a szczególnie kontaktów z matką Małgorzatą, która później stanie się w jego wspólnocie

${ }^{32}$ Teresio Bosco, Złote myśli Księdza Bosko (Warszawa: Wydawnictwo Salezjańskie, 2002), 131.

${ }^{33}$ Cian, Wychowanie, 242-243.

${ }^{34}$ Cyt. za: Cian, System zapobiegawczy, 32. W innym miejscu Jan Bosko podkreśla: „Z miłości chrześcijańskiej trzeba zdobyć się na wielki wysiłek, aby młodzi ludzie czynili dobro, a unikali zła kierując się uformowanym przez wiarę sumieniem" (Pozwól, 41).

35 Bosko, „List z Rzymu”, 222. 
opiekunką przybywających chłopców, niejednokrotnie pozbawionych domu rodzinnego.

Dla wielu, pozbawionych prawdziwego bogactwa uczuć czy po prostu biednych, ksiądz Bosko tworzył, poprzez styl «formacji rodzinnej», odpowiednią atmosferę, w której dawał szerokie możliwości kontaktów ojcowsko-macierzyńskich, braterskich, przyjacielskich, zdolnych do odrodzenia życia uczuciowego, aby wychowanek mógł zaangażować się zarówno emocjonalnie, jak i praktycznie ${ }^{36}$.

Rodzinę można określić jako ,pierwotny rdzeń uczuciowy”, który jest podstawą wyjściową dla ukształtowania osoby i konkretyzuje się w serii życiowych czynników, tworzących prawdziwego «ducha rodzinnego». Rodzina jak stwierdza Bruno Ferrero we wskazaniach dla rodziców, biorąc za podstawę system prewencyjny Jana Bosko - jest miejscem przebaczenia w całym tego słowa znaczeniu. Zatem:

- człowiek uczy się umiejętności przebaczenia przez doświadczenie, uczy się przebaczać od własnych rodziców;

- prawdziwe przebaczenie dotyczy spraw ważnych, jest ono aktem heroicznym;

- przebaczenie nie zamazuje prawdy;

- przebaczenie nie jest słabością;

- prawdziwe przebaczenie jest zwycięskie, jest zawsze zastrzykiem nadziei;

- prawdziwe przebaczenie rzeczywiście zapomina o winie;

- konieczne jest ćwiczenie, siła przebaczenia drzemie w nas i trzeba je wydobyć;

- jest zawsze wyrazem prawdziwej miłości;

- «ponieważ nie wiedzą, co czynią»: przebaczenie jest ręką wyciągniętą w geście pomocy i poprawy;

${ }^{36}$ Braido, Prevenire, 241. „Wybór takiego właśnie «domowego wychowania» był świadomy, ponieważ poprzedzony długim doświadczeniem obecności wśród konkretnej młodzieży, która była niezwykle spragniona uczestnictwa w klimacie rodzinnym. Poza tym tylko doświadczenie tego klimatu może sprawić, że wychowanek zrozumie także istotę uczestnictwa w rodzinie dzieci Bożych. [...] Duch rodzinny, który w naturalny sposób przywołuje kategorię asystencji czy też obecności wychowawczej, sprawia, że środowisko staje się radosne, pogodne i mobilizujace" (Bissoli, Jan Pawet II, 88). 
- jednym z fundamentów wychowawczego systemu salezjańskiego jest sakrament pojednania. Ksiądz Bosko wiedział dobrze, że ten, któremu przebaczono, łatwiej potem sam przebacza $^{37}$.

Miłość, zaufanie, wyrozumiałość, serdeczny kontakt i radość - to istotne elementy systemu wychowawczego nastawionego na skuteczność. Przebaczenie jest zatem darem, jaki ofiaruje się drugiemu człowiekowi. W takiej perspektywie w miłości można wychowywać wszystkim: postawą, obecnością, gestem, ciepłem, trwaniem, troską, pomocą, opieką, a także sobą samym. „Bądźcie wytrwali - podkreśla Jan Bosko - w pragnieniu dobra i przeciwstawianiu się złu, ale bądźcie zawsze łagodni i ostrożni, wytrwali i pełni miłości”38.

5) miłość wychowawcza jest dla księdza Bosko w pierwszym rzędzie miłością ewangeliczną i opiera się całkowicie na słowach św. Pawła: „miłość cierpliwa jest..., wszystko znosi..., we wszystkim pokłada nadzieję..., wszystko przetrzyma..." (por. 1 Kor 13, 4-7). System prewencyjny inspiruje się miłością Bożą.

Niekiedy wydaje się nam - stwierdza Jan Bosko - że ten chłopiec nie odnosi żadnego pożytku z naszego napomnienia, podczas gdy w rzeczywistości ma on w swym sercu jak najlepsze usposobienie, by pójść za naszą radą, ale my potem wszystko niweczymy przez stosowanie źle pojętego rygoru i wymaganie, by winny poniósł natychmiastową i ciężką pokutę za swój błąd. [...] Trzeba zostawić mu czas na zastanowienie się, wejście w siebie, przeżycie w pełni popelnionego zla, a jednocześnie odczucie potrzeby sprawiedliwości i koniecznej kary, a przez to umożliwienie mu wyciągnięcia właściwych wniosków ${ }^{39}$.

${ }^{37}$ Por. Bruno Ferrero, Rodzice szczęśliwi dzięki metodzie wychowawczej księdza Bosko (Warszawa: Wydawnictwo Salezjańskie, 2005), 73-75.

38 Bosco, Ztote myśli, 48.

39 Jan Bosko, „O stosowaniu kar w domach salezjańskich”, w: Cian, System zapobiegawczy, 234-236. „Właściwie rozumiana sprawiedliwość stanowi poniekąd cel przebaczenia. W żadnym miejscu orędzia ewangelicznego ani przebaczenie, ani też miłosierdzie jako jego źródło, nie oznacza pobłażliwości wobec zła, wobec zgorszenia, wobec krzywdy czy zniewagi wyrządzonej. W każdym wypadku naprawienie tego zła, naprawienie zgorszenia, wyrównanie krzywdy, zadośćuczynienie za zniewagę, jest warunkiem przebaczenia. Tak więc podstawowa struktura sprawiedliwości wkracza zawsze na obszar miłosierdzia. To ostatnie posiada jednakże moc wypełnienia sprawiedliwości nową treścią. Treść ta najprościej i najpełniej uwydatnia się w przebaczeniu. Ono bowiem ukazuje, iż poza całym procesem «wyrównawczym» czy też «rozejmowym», który właściwy jest dla samej sprawiedliwości, dochodzi do głosu miłość, czyli 
Jest to zatem miłość, która potrafi docierać do ostatnich, najbardziej skromnych i tych, którzy mają największe trudności. Miłość ta łączy duchową gorliwość z mądrością, taktem pedagogicznym, zmysłem praktycznym, optymizmem wychowawczym i cierpliwością tych, którzy mają wspierać i troszczyć się o zalążki życia. Jednym słowem jest to miłość ojcowska, która uczy, jak przejść przez życie. Trzy wzorcowe biografie napisane przez księdza Bosko pokazują, w jaki sposób można wynieść na wysoki poziom życia chrześcijańskiego kogoś, kto jest do tego w szczególny sposób predestynowany (Dominik Savio), albo odzyskać kogoś, kto miał mniej sprzyjającą przeszłość (Michał Magone), lub towarzyszyć aż do satysfakcjonującego momentu rozwoju komuś, kto miał warunki normalne (Franciszek Besucco). System prewencyjny był dla niego miłością darmo daną, czerpaną z miłości samego Boga ${ }^{40}$. „Chrześcijańskie doświadczenie przebaczenia nie kończy się na darmowym otrzymaniu daru od Boga, lecz przechodzi od doświadczenia biernego, kiedy nam zostaje przebaczone, do doświadczenia aktywnego, kiedy to my przebaczamy, jako zadania, do którego każdy człowiek jest powołany"41.

$* * *$

Osobiste doświadczenie i myśl ks. Jana Bosko o konieczności wychowania i wychowawcy dla rozwoju ludzkiego i chrześcijańskiego człowieka mają swe korzenie w chrześcijańskiej wizji człowieka, w realistycznym humanizmie, który go cechował, a który pochodził z jego wiary i miłości do człowieka.

Wszystko musi być rozumne: regulamin, rozkazy i polecenia, kiedy trzeba je ogłosić; środowisko, nie powinno thumić życia, które pulsuje tysiącem czynników i kształtuje się; wszystkie gesty, które tworzą codzienny kontekst, powin-

afirmacja człowieka. Spełnienie zaś warunków sprawiedliwości jest nade wszystko nieodzowne, ażeby ta miłość mogła niejako odsłonić swoje oblicze. Tak jak na to już zwracaliśmy uwagę przy analizie przypowieści o synu marnotrawnym, ten, kto przebacza i ten, który dostępuje przebaczenia, spotykają się z sobą w jednym zasadniczym punkcie: tym punktem jest godność, czyli istotna wartość człowieka, która nie może być zagubiona, której potwierdzenie czy odnalezienie stanowi też źródło największej radości (por. Łk 15, 32)” (Jan Paweł II, „Encyklika Dives in misericordia", nr 14, w: Encykliki Ojca Świętego Jana Pawła II, t. 1 (Kraków: Wydawnictwo św. Stanisława B.M. Archidiecezji Krakowskiej, Wydawnictwo M, 1996), 95).

${ }^{40}$ Por. Vecchi, Duchowość, 105-117.

${ }^{41}$ Giulianini, O przebaczaniu, 98. 
ny być inspirowane spontanicznością, a nie strachem lub obawą; wreszcie kara i nagroda. A wszystko to w tym celu, by wychowanek mógł zaspokoić dwie potrzeby fundamentalne: działanie $\mathrm{z}$ wolnego wyboru i potwierdzenie własnej osobowości. Nie wychowuje się, krępując wolność drugiego, ale pomagając mu używać jej dobrze; nie wyklucza się możliwości błędów i nadużyć, owszem nie chodzi nawet o unikanie ich w granicach pewnej naturalnej roztropności, ponieważ możliwość zetknięcia się z nimi daje sposobność do naprawienia w sposób bezpośredni owych niedoświadczonych i niedoskonałych czynów popełnianych często na skutek odruchowego działania ${ }^{42}$.

Ksiądz Bosko nie miał przed sobą jedynie Dominika Savio, czyli chłopców dobrze ułożonych (wychowanych), przychodzących z idealnego wychowania rodzinnego, które uczyniło ich zdolnymi do dobra. W stosunku do każdego chłopca powtarzał trudną, niepewną, bolesną wędrówkę pierwszego Oratorium: chłopiec (wychowanek) rodził się temu samemu sobie, który był ukryty pośród zawiłości jego człowieczeństwa i stał się możliwy dzięki ła$\mathrm{sce}^{43}$. Zatem:

wartość przebaczenia, pamiętając o trudnościach wykonawczych, jakie ze sobą pociąga, w kontekście cierpienia, w którym dojrzewa i efektach psychologicznych i duchowych, jakie wywołuje, stanowi ważny element, który może pobudzać człowieka do dojrzałości nie tylko z psychicznego punktu widzenia, lecz także do przejrzenia dziecięcych reprezentacji, które często kierują jego życiem duchowym w wieku dojrzałym ${ }^{44}$.

\section{Educating for Forgiveness in Saleisan Pedagogy (Summary)}

The question of education always comes down to the individual. In this educational process, taking place between the teacher and the pupil, the teacher makes conscious efforts to broaden and enrich the pupil's repertoire of behaviours and attitudes. One of the important values in human life is forgiveness, which is one of those concepts subject to formation and development. It can therefore be concluded that

${ }^{42}$ Cian, System zapobiegawczy, 64-65.

${ }^{43}$ Por. Guido Gatti, Zawód: wychowawca chrześcijański (Warszawa: Wydawnictwo Salezjańskie, 1997), 31-33.

${ }^{44}$ Giulianini, O przebaczaniu, 136. 
this is a dynamic, transformative act, which not only implies a change in the inner attitude of the person who forgives, but also affects the person forgiven, causing a change in his situation. The personal experience and the thought of Father John Bosco about the necessity of education and educators for the human and Christian development of man have their roots in the Christian vision of man, in the realistic humanism that characterized him and which came from his faith and love for man. The Preventive System is mercy in action. The educational idea of Don Bosco is placed in the context of great challenges and needs, relates to the very nature of prevention and emphasized that true love requires the enduring of mistakes of others with patience and a willingness to forgive. Through love, the teacher creates a climate of true ,pedagogical presence", a creative and liberating presence, and reveals the entire multifaceted and multidimensional context of the situation and the processes of education, including educating for forgiveness.

Key words: education; forgiveness; preventive system; educational love.

\section{Wychowanie do przebaczenia w pedagogii salezjańskiej (Streszczenie)}

Problematyka wychowawcza dotyczy zawsze konkretnego człowieka. W procesie wychowania, zachodzącym pomiędzy wychowawcą i wychowankiem, wychowawca podejmuje świadome działania na rzecz poszerzenia i ubogacenia repertuaru zachowań oraz postaw wychowanka. Jedną z wartości istotnych w życiu człowieka jest przebaczenie i należy do tych, które podlegają kształtowaniu i rozwojowi. Można stwierdzić, iż przebaczenie to akt dynamiczny, przekształcający, który nie implikuje jedynie zmiany w wewnętrznym nastawieniu osoby, która przebacza, lecz wywołuje efekty także w osobie, która dostępuje przebaczenia, powoduje zmianę w jej sytuacji. Osobiste doświadczenie i myśl księdza Jana Bosko o konieczności wychowania i wychowawcy dla rozwoju ludzkiego i chrześcijańskiego człowieka mają swe korzenie w chrześcijańskiej wizji człowieka, w realistycznym humanizmie, który go cechował, a który pochodził z jego wiary i miłości do człowieka. System prewencyjny jest miłosierdziem w działaniu. Myśl wychowawcza księdza Bosko jest umieszczona w kontekście wielkich wyzwań i potrzeb, odnosi się do samej natury działań prewencyjnych i podkreśla, iż: prawdziwa miłość nakazuje błędy innych znosić z cierpliwością i chętnie przebaczać. Przez miłość wychowawca tworzy klimat prawdziwej „,pedagogicznej obecności”, obecności twórczej i wyzwalającej, odsłania cały wieloproblemowy i wieloaspektowy kontekst uwarunkowań dla sytuacji i procesów wychowania, w tym także wychowania do przebaczenia. 
Słowa kluczowe: wychowanie; przebaczenie; system prewencyjny; miłość wychowawcza.

\section{Bibliografia}

Aletti, Mario. „Przedmowa. Przebaczenie i przedefiniowanie osobistej tożsamości”. W: Annalisa Giulianini, O przebaczaniu, czyli jak uleczyć duszę. Psychologiczne i duchowe sprzeczności, 7-12. Kraków: Wydawnictwo OO. Franciszkanów „Bratni Zew”, 2008.

Balduzzi, Emanuele. La pedagogia alla prova della virtù. Emozioni, empatia e perdono nella pratica educativa. Milano: Vita e Pensiero, 2015.

Bissoli, Cesare. Jan Pawet II o systemie wychowawczym księdza Bosko. Warszawa: Wydawnictwo Salezjańskie, 2001.

Bosco, Teresio. Złote myśli Księdza Bosko. Warszawa: Wydawnictwo Salezjańskie, 2002.

Bosko, Jan. „List o karach”. W: Luciano Cian, Wychowanie w duchu Księdza Bosko, 259-268. Warszawa: Wydawnictwo Salezjańskie, 1990.

Bosko, Jan. „List z Rzymu”, W: Wspótczesny wychowawca w stylu księdza Bosko, red. Józef Wilk, 221-231. Lublin: Poligrafia Inspektoratu Towarzystwa Salezjańskiego, 1998.

Bosko, Jan. „O stosowaniu kar w domach salezjańskich”. W: Luciano Cian, System zapobiegawczy św. Jana Bosko i jego charakterystyka, 231-244. Warszawa: Wydawnictwo Salezjańskie, 2001.

Bosko, Jan. „System prewencyjny w wychowaniu młodzieży”. W: Wspótczesny wychowawca w stylu księdza Bosko, red. Józef Wilk, 213-219. Lublin: Poligrafia Inspektoratu Towarzystwa Salezjańskiego, 1998.

Braido, Pietro. Prevenire non reprimere. Il sistema educativo di don Bosco. Roma: LAS, 1999.

Chrobak, Stanisław. „Podstawowe wartości wspólnoty jako środowiska wychowawczego w systemie prewencyjnym św. Jana Bosko”. W: Kształtowanie się środowisk wychowawczych dzieci i młodzieży na przestrzeni dziejów, red. Barbara Moraczewska, Piotr Krzywicki, 138-148. Włocławek: Państwowa Wyższa Szkoła Zawodowa we Włocławku, 2014.

Cian, Luciano. System zapobiegawczy św. Jana Bosko i jego charakterystyka. Warszawa: Wydawnictwo Salezjańskie, 2001.

Cian, Luciano. Wychowanie w duchu Księdza Bosko. Warszawa: Wydawnictwo Salezjańskie, 1990. 
De Pieri, Severino. Ukierunkowanie w wychowaniu $i$ towarzyszenie powolaniu. Warszawa: Wydawnictwo Salezjańskie, 2002.

Ferrero, Bruno. Rodzice szczęśliwi dzięki metodzie wychowawczej księdza Bosko. Warszawa: Wydawnictwo Salezjańskie, 2005.

Gadacz, Tadeusz. O ulotności życia. Warszawa: Wydawnictwo Iskry, 2008.

Gatti, Guido. Zawód: wychowawca chrześcijański. Warszawa: Wydawnictwo Salezjańskie, 1997.

Giulianini, Annalisa. O przebaczaniu, czyli jak uleczyć duszę. Psychologiczne i duchowe sprzeczności. Kraków: Wydawnictwo OO. Franciszkanów „Bratni Zew", 2008.

Il sistema preventivo e l'educazione dei Giovani, red. Carlo Nanni. Roma: LAS, 1989.

„Jak ksiądz Bosko, z młodzieżą i dla młodzieży. List Ojca Świętego Franciszka w Dwusetlecie urodzin św. Jana Bosko". W: Ksiądz Bosko w wypowiedziach papieży, cz. 2, red. Stanisław Chrobak, 283-288. Warszawa: Wydawnictwo Salezjańskie, 2015.

Jan Paweł II. „Encyklika Dives in misericordia”. W: Encykliki Ojca Świętego Jana Pawła II, t. 1, 55-99. Kraków: Wydawnictwo św. Stanisława B.M. Archidiecezji Krakowskiej, Wydawnictwo M, 1996.

Jan Paweł II. „List apostolski Iuvenum patris w setną rocznicę śmierci św. Jana Bosko". W: Ksiadz Bosko w wypowiedziach papieży, cz. 2, red. Stanisław Chrobak, 75-94. Warszawa: Wydawnictwo Salezjańskie, 2015.

Król, Aldona. „Wychowanie do przebaczenia”. W: Wychowanie chrześcijańskie między tradycją a wspótczesnościa, red. Alina Rynio, 431-442. Lublin: Wydawnictwo KUL, 2007.

Łobocki, Mieczysław. „Współczesne tendencje w wychowaniu a system wychowawczy św. Jana Bosko". W: Ksiądz Bosko i jego system wychowawczy, red. Jan Niewęgłowski, 264-274. Warszawa: Wydawnictwo Salezjańskie, 2000.

Misiaszek, Kazimierz. „Pedagogia salezjanów”. W: Pedagogie katolickich zgromadzeń zakonnych. Historia i współczesność, t. 1, red. Janina Kostkiewicz, 229-269. Kraków: Impuls, 2012.

Narecki, Zbigniew. ,Wartość przebaczenia i pojednania w pryzmacie współczesności”. Pedagogia Ojcostwa 10, 1 (2015): 39-54.

Nowak, Marian. Podstawy pedagogiki otwartej. Ujęcie dynamiczne w inspiracji chrześcijańskiej. Lublin: Redakcja Wydawnictw Katolickiego Uniwersytetu Lubelskiego, 1999.

Nowak, Marian. Teorie i koncepcje wychowania. Warszawa: Wydawnictwa Akademickie i Profesjonalne, 2008. 
Nowosielski, Mirosław. „Przebaczenie - trudny problem widziany z perspektywy psychologicznej”. Ateneum Kapłańskie 156, 2 (2011): 223-232.

Orzelska, Julita. W stronę pedagogiki istotnej egzystencjalnie. Kraków: Impuls, 2014.

Ostrowska, Krystyna. Wokót rozwoju osobowości i systemu wartości. Warszawa:

Centrum Metodyczne Pomocy Psychologiczno-Pedagogicznej Ministerstwa Edukacji Narodowej, 1998.

Pellegrino, Giuseppe. Jak wychowywać? Warszawa: Wydawnictwo Salezjańskie, 1994.

Pieper, Josef. O miłości. Warszawa: Instytut Wydawniczy Pax, 2004.

Pozwól gwizdać szpakom. Wybór myśli i wskazań św. Jana Bosko dla młodzieży i starszych, red. Stanisław Szmidt. Warszawa: Wydawnictwo Salezjańskie, 1998.

Sakowicz, Eugeniusz. „Przebaczenie w religiach niechrześcijańskich”. Ateneum Kaplańskie 156, 2 (2011): 270-275.

Vecchi, Juan E. Duchowość salezjańska. Warszawa: Wydawnictwo Salezjańskie, 1999.

Vecchi, Juan E. Strażnicy marzeń z palcem na myszce. Wychowawcy $w$ dobie informatyki. Warszawa: Wydawnictwo Salezjańskie, 2001.

Weinschenk, Reinhold. Podstawy pedagogiki Księdza Bosko. Warszawa: Wydawnictwo Salezjańskie, 1996. 